\title{
Factors Determining the Willingness to Adopt Grasscutter Domestication Technology among Urban Dwellers in Southwest, Nigeria
}

\author{
BANJO, AA; TOKEDE, AM; OGUNSOLA, AJ; NOSIRU, MO; *AHMAD, AO; \\ OYANIYI, T
}

Department of Forest Economics and Extension, Forestry Research Institute of Nigeria, Ibadan, Nigeria *Corresponding Author Email: ahmadsquare8@gmail.com; Tel: +2348030831610

\begin{abstract}
This study investigated factors determining the willingness to adopt grasscutter domestication technology in South west, Nigeria. Multi-stage sampling procedure was used to select 160 respondents from 9 urban towns in Oyo, Ogun and Osun States. Well-structured questionnaire was used for data collection. Data was analysed using descriptive analysis, correlational analysis and t-test. Results showed that the majority (69.4\%) of the respondents were male and married. Coefficient correlation ( $\mathrm{r}$ value) at $(\mathrm{p}<0.05)$, shows that there is a significant association between respondents' educational status, religion, household size, primary as well as secondary education with respondents' willingness to adopt the technology. There was also found significant relationship between, perceived health status of those who are into the grasscutter technology, perceived nutritional value and economic value of the grasscutter domestication technology with the willingness to adopt the grasscutter domestication technology. The result if the T-test revealed that there is significant relationship between perceived ease of practice and willingness to adopt the technology. The majority of the respondents are willing to rear grasscutter if variables like space, fund, availability of ready-made buyer and feed, breeding stock and training are put into place. However, issues relating to having enough plots of land, funding, ready-made buyer of grasscutter, and training facilities are most germane. It is therefore recommended that funding and training on the adoption of the grasscutter domestication technology should be made available to individuals.
\end{abstract}

\section{DOI: https://dx.doi.org/10.4314/jasem.v24i11.13}

Copyright: Copyright (C) 2020 Banjo et al. This is an open access article distributed under the Creative Commons Attribution License (CCL), which permits unrestricted use, distribution, and reproduction in any medium, provided the original work is properly cited.

Dates: Received: 20 September 2020; Revised: 29 October 2020; Accepted: 10 November 2020

Keywords: grasscutter, technology, urban dwellers, southwest Nigeria

Globally, wildlife has great potentials for meat production and serves as an important source of the highly desired animal protein for both urban and rural communities (Adedapo and Aekunle, 2014). The importance of animal protein in human nutrition cannot be over emphasized (Owen, Alawa, Wekhe, Isirimah, Chukuigwe and Aniebo, 2009; Owen and Amakiri, 2009). Lack of protein has been implicated as the major factor that inhibited the physical and mental growth of millions of children in Africa for generations (West Africa trends, 2014), because in recent times, there had been significant short fall between the production and supply of animal protein to feed the ever increasing population (Akinola et al., 2015). However, with ever increasing human population and obvious protein shortage in Nigeria, West Africa, there is the need for an exploration of other means to provide readily acceptable meat on short term basis. According to an FAO Document Repository on Wildlife utilization and food security in Africa, there is no doubt at all that domestication and farming of favourite "wild animal species" could provide viable complementary or alternative sources of animal protein. However, the key to its acceptance on a wide scale depends on the development of technical know-how and cheap methods of production (http://www.fao.org/docrep). To arrest this unacceptable trend, efforts had been directed towards boosting the micro livestock sector. Among the microlivestock species is the Grasscutter or cane rat, which is a heavily built animal with round muzzle, small round ears, short tail and harsh bristly fur. Apart from being the most preferred, it is the most expensive bush meat in most West African countries, Southwest, Nigeria inclusive (Olatidoye et al.,2018). It contributes to both local and foreign earnings in some of these countries. Most rural populations in Nigeria depend on bush meat for their dietary protein supply and most Chinese who are resident in Nigeria cherish Grasscutter meat as regular meal and forms delicacy for entertainment for their guest from abroad (Olukole, et al., 2010) As earlier highlighted, wildlife domestication has been recognized as the best way of achieving this objective (Ajayi, 2010). Studies conducted by Akinola et al. (2015) and Olatidoye et al. (2018) revealed that Grasscutter production in Southwest, Nigeria, is mainly at subsistence level and output is relatively low despite its relatively 
competitive prices in both local and international market. It is therefore important to consider factors intrinsic and extrinsic that determines the urban dwellers willingness to adopt the grasscutter domestication technology. However, the willingness to adopt the technology is pivotal to the adoption of such technology. Barriers to technology adoption include, personal characteristics of individuals, a lack of awareness, access, skills and experience (Hargittai, 2002) insufficient training (Cotten, Yost, Berkowsky, Winstead and Anderson, 2016; Czaja and Sharit, 2013), decreased confidence in ability to use technology (Czaja et al., 2006: Siren and Knudsen, 2017). However, these barriers do not fully explain why individuals in the urban areas of Southwest, Nigeria may be less willing to adopt the technology, other factors, such as perceptions regarding economic and nutritional value and ease of practice and health status should be considered. The knowledge of these factors and their interrelationships can provide important information towards the development of strategies to promote greater technology adoption by urbanites which could in turn result in improvements in quality of life. It is against the background, this study explored the influence of personal characteristics of individuals, perceived economic and nutritional value, and perceived ease of rearing of the grasscutter and health status of the individual as they determine the willingness to adopt the grasscutter domestication technology. Therefore, the objective of this paper is to evaluate the factors determining the willingness to adopt grasscutter domestication among urban dwellersin southwest Nigeria.

\section{MATERIALS AND METHOD}

Study area: The study was carried out in South west, Nigeria. It comprised of six states, Oyo, Ondo, Ogun, Osun, Ekiti and Lagos states. The area lies between longitude 2.031 and 6000 1East and latitude 6021 and $80371 \mathrm{~N}$ with a total area of $77,818 \mathrm{~km} 2$. National Population Commission (2007) reported that 27511892 people lived in Southwest Nigeria. Agriculture is one of the major source of income for greater number of people in the States providing food and shelter, employment, raw materials and remains an important source of internally generated revenue in the states. The climate is tropical with distinct wet and dry season with temperature ranging between $22-380 \mathrm{C}$ which favors the growth of food crops like yam, cassava, millet, maize, fruits, vegetables, plantains, cocoa and tobacco. Livestock like ruminant, poultry, fish and forest animals like grasscutter which also can be found in thick forest riverine areas are also found in the State. The state has two vegetation zones which are derived savannah and forest zones.
Sample/Data Collection: Multi-stage sampling procedure was used for the study. At stage one, random selection of 3 states (Oyo, Ogun, Osun) was done. At stage two, eight urban settlements were purposively selected from the three states (Ibadan, Ogbomosho and Eruwa from Oyo state, Abeokuta and Ijebu-ode from Ogun state, Oshogbo, Ife and Ilesha from Osun state). At stage three 20 urban dwellers were selected from each of the urban settlements to make a total of one hundred and sixty (160) respondents.

Well-structured questionnaire was used to determine respondents' socio-economic characteristics, perceived economic and nutritional value, perceived effect of the grasscutter domestication technology on their health status, perceived ease of practice as they all affect respondents' willingness to adopt the grasscutter domestication technology in the study area as the dependent variable.

Sample/Data Analysis: The data collected were analysed through descriptive survey, (percentage tables, chats and frequency tables) while inferential statistics, such as the coefficient correlation, Pearson rank correlation and $\mathrm{T}$ - test were used to draw inferences between the variables in the hypotheses.

\section{RESULTS AND DISCUSSION}

According to table $1,69.4 \%$ of the respondents are males while the remaining $30.6 \%$ are females. $45.6 \%$ have tertiary education while just $3.1 \%$ have no formal education. Majority (73.1\%) are married, 26.4\% are less than 30 years and also between $31-40$ years, while the least percentage $(5 \%)$ of respondents are 60 years and above. $60 \%$ are Christians, $35.6 \%$ are Muslims while $4.4 \%$ practice Traditional religion. $33.3 \%$ of the respondents' household size is $1-5,25.6 \%$ has $6-8$, $24.4 \%$ has $12-14,14.4 \%$ has $9-11$ while $1.9 \%$ has more than 15 household size. $55.1 \%$ of the respondents has farming as their primary occupation, while the least percentage of respondents $(1.3 \%)$ are retirees. $47.5 \%$ of the respondents work with private firms as secondary occupation, while just $2.5 \%$ are sole proprietors. Majority of the respondents (69\%) are resident in their personal homes while just 31.0\% are living in rented apartments. Table 2 displayed the response of respondents to 13 perception statements on the economic value of the cane rat. Statement 9 'Grasscutter has longer gestation period than other rodents' ranked first with the highest mean of 2.75, followed by statement 3 , There is a high risk of epidemics among grasscutters with a mean of 2.67 and statement 13 'All together rearing grasscutter is very expensive 'ranked $3^{\text {rd }}$ with a mean of 2.65 , while statement 6' Domesticated grasscutter does not grow 
well as compared to the one in the wild' ranked lowest with a mean of 1.81 . According to this result, 'the grasscutter has longer gestation period than other rodents' $(x=2.75)$ and 'all together rearing grasscutter is very expensive' $(x=2.65)$ had the highest mean value above 2.30 the grand mean value The implication is that most respondents see the following perception statements 'the longer gestation of cane rat', its high risk of epidemic' and 'its expensive cost of rearing' as major deterrents to its ability to give high economic yield.

Table 1: Frequency of socio demographic and other baseline information of participants, a cross-sectional study on effect of cultural beliefs and health status on the willingness to adopt grasscutter technology in South-West

\begin{tabular}{|c|c|c|c|}
\hline Gender $(\mathrm{N}=160)$ & $\mathrm{N}(\%)$ & Household size $(\mathrm{N}=160)$ & $\mathrm{N}(\%)$ \\
\hline Male & $111(69.4)$ & $1-5$ & $54(33.8)$ \\
\hline Female & $49(30.6)$ & $6-8$ & $41(25.6)$ \\
\hline Educational Status $(\mathrm{N}=160)$ & & $9-11$ & $23(14.4)$ \\
\hline No Formal & $5(3.1)$ & $12-14$ & $39(24.4)$ \\
\hline Primary & $22(13.8)$ & $15+$ & $3(1.9)$ \\
\hline Secondary & $60(37.5)$ & Primary Occupation $(\mathrm{N}=160)$ & \\
\hline Tertiary & $73(45.6)$ & Civil servant & $17(10.8)$ \\
\hline Marital Status $(\mathrm{N}=160)$ & & Private Firm & $19(12.0)$ \\
\hline Single & $25(15.6)$ & Sole proprietor & $18(11.4)$ \\
\hline Married & $117(73.1)$ & Farming & $87(55.1)$ \\
\hline Widow & $13(8.1)$ & Retiree & $2(1.3)$ \\
\hline Separated & $4(2.5)$ & Schooling & $15(9.5)$ \\
\hline Divorced & $1(0.6)$ & Secondary Occupation $(\mathrm{N}=160)$ & \\
\hline Age range $(\mathrm{N}=160)$ & & Civil Servant & $63(39.4)$ \\
\hline$<30$ years & $42(26.4)$ & Work with private firm & $76(47.5)$ \\
\hline $31-40$ years & $42(26.4)$ & Sole Proprietorship & $4(2.5)$ \\
\hline $41-50$ years & $41(25.7)$ & Farming & $17(10.6)$ \\
\hline $51-60$ years & $27(17)$ & & \\
\hline $60+$ & $8(5)$ & & \\
\hline Religion $(\mathrm{N}=160)$ & & Residential Apartment $(\mathrm{N}=160)$ & \\
\hline Christianity & $96(60.0)$ & Personal & $107(69.0)$ \\
\hline Islam & $57(35.6)$ & Rented & $48(31.0)$ \\
\hline Traditional & $7(4.4)$ & & \\
\hline
\end{tabular}

Source: Analysis, 2020

Table 2: Response of the participants on the variables related with grasscutter technology, a cross-sectional study on assessment of

\begin{tabular}{|c|c|c|c|c|c|c|}
\hline Economic Value & $\begin{array}{l}\text { Strongly } \\
\text { Agree }\end{array}$ & Agree & Disagree & $\begin{array}{l}\text { Strongly } \\
\text { Disagree }\end{array}$ & Mean & Rank \\
\hline Buying the stock is capital intensive. & $33(20.6)$ & $71(44.4)$ & $44(27.5)$ & $12(7.5)$ & 2.22 & $8^{\mathrm{TH}}$ \\
\hline Constructing grasscutter pen is capital intensive. & $37(23.1)$ & $80(50)$ & 35 (21.9) & $8(5.0)$ & 2.09 & $10^{\mathrm{TH}}$ \\
\hline $\begin{array}{l}\text { There is a high risk of epidemics among } \\
\text { grasscutters. }\end{array}$ & $7(4.4)$ & $65(40.9)$ & $61(38.4)$ & $26(16.4)$ & 2.67 & $2^{\mathrm{ND}}$ \\
\hline The cost of treatment for grasscutter is high. & $15(9.4)$ & $65(40.6)$ & $62(38.8)$ & $18(11.3)$ & 2.52 & $4^{\mathrm{TH}}$ \\
\hline Grasscutter has poor marketability. & $55(35.5)$ & $59(38.1)$ & $30(19.4)$ & $11(7.1)$ & 1.98 & $11^{\mathrm{TH}}$ \\
\hline $\begin{array}{l}\text { Domesticated grasscutter does not grow well as } \\
\text { compared to the one in the wild. }\end{array}$ & $59(36.9)$ & $75(46.9)$ & $23(14.4)$ & $3(1.9)$ & 1.81 & $13^{\mathrm{TH}}$ \\
\hline Grasscutters are prone to predators. & $23(14.6)$ & $70(44.3)$ & $62(39.2)$ & $3(1.9)$ & 2.28 & $7^{\mathrm{TH}}$ \\
\hline Feeding grasscutter is very expensive. & $15(9.4)$ & $77(48.4)$ & $58(36.5)$ & $9(5.7)$ & 2.38 & $6^{\mathrm{TH}}$ \\
\hline $\begin{array}{l}\text { Grasscutter has longer gestation period than other } \\
\text { rodents. }\end{array}$ & $10(6.3)$ & $41(25.8)$ & $86(54.1)$ & $22(13.8)$ & 2.75 & $1^{\mathrm{ST}}$ \\
\hline $\begin{array}{l}\text { Grasscutters give births to fewer off springs } \\
\text { compared to other rodents. }\end{array}$ & $21(13.1)$ & $57(35.6)$ & $63(39.4)$ & $19(11.9)$ & 2.50 & $5^{\mathrm{TH}}$ \\
\hline Rearing grasscutter has low profit margin. & $41(25.6)$ & $97(60.6)$ & $19(11.9)$ & $3(1.9)$ & 1.90 & $12^{\mathrm{TH}}$ \\
\hline $\begin{array}{l}\text { There is high risk of theft, since grasscutters don't } \\
\text { make much noise }\end{array}$ & $35(22.0)$ & $75(47.2)$ & $38(23.9)$ & $11(6.9)$ & 2.16 & $9^{\mathrm{TH}}$ \\
\hline All together rearing grasscutter is very expensive. & $10(6.3)$ & $75(46.5)$ & $67(41.5)$ & $8(5.0)$ & 2.65 & $3^{\mathrm{RD}}$ \\
\hline
\end{tabular}

Source: Field survey (2020).

Table 3 exposed the response of respondents to 5 perception statements on the nutritive value of the cane rat. Statement 2' Domesticated grasscutter has lower nutritional benefits compared to the one in the wild' ranked $1^{\text {st }}$ with a mean of 2.76 , statement 1
'Domesticated grasscutter is not as nutritious as compared to the one in the wild' ranked $2^{\text {nd }}$ with a mean of 2.50, statement 5' Grasscutter meat does not have any medicinal value' ranked $3^{\text {rd }}$ with 2.30 , followed by statement 3 'Grasscutter is not nutritious' 
with 2.25 while statement 4 'Grasscutter has higher protein content compared to other animals' ranked $5^{\text {th }}$ with a mean of 1.99. According to this result, only the following perception statements 'domesticated grasscutter is not as nutritious as compared to the one in the wild' $(x=2.76)$ and 'grasscutter meat does not have any medicinal value' $(\mathrm{x}=2.50)$ had mean value above 2.36 , the grand mean value. The implication is that many respondents perceive statement 2,1 and 5 as reasons they do not perceive the domesticated cane rat meat as nutritious. Table 4 displayed the response of respondents to 7 perception statements on the effect of the cane rat technology on human health conditions. Statement 7' Humans consuming grasscutter meat are liable to catching various diseases' ranked $1^{\text {st }}$, followed by statement 6 ' The odour emanating from grasscutter habitat is quite offensive' with a mean of

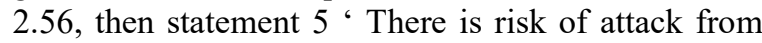
domesticated grasscutters on humans' with 2.51, statement 1' The odour emanating from the grass cutters' habitat gives me allergy' with a mean score of 2.49 , then statement 4 'Grasscutter meat is bad for hypertensive patients' ranked $5^{\text {th }}$ with 2.47 , followed by statement 2 'There is a high risk of grasscutter spreading contagious diseases to humans' ranking $6^{\text {th }}$ with 2.44 and lastly statement 3 'Grasscutter meat is bad for diabetic patients' ranking $7^{\text {th }}$ with 2.13 . According to this result, the following perception statements 'the human consuming grasscutter meat are liable to catching various diseases' $(\mathrm{x}=2.62)$ 'the odour emanating from grasscutter habitat is quite expensive' $(\mathrm{x}=2.56)$ and there is risk of attack from domesticated grasscutters on humans $(x=2.51)$ had the highest mean value above 2.46 , the grand mean value The implication from this result is that the response is divergent, however statement $7,6,5$ accounted for the major implications of cane rat technology on the health status of humans according to the respondents.

Table 3: Response of the participants on the variables related with grasscutter technology, a cross-sectional study on assessment of

\begin{tabular}{lllllll}
\multicolumn{7}{c}{ nutritional value of grasscutter technology in South-West } \\
\hline Nutritional Value & $\begin{array}{l}\text { Strongly } \\
\text { Agree }\end{array}$ & Agree & Disagree & $\begin{array}{l}\text { Strongly } \\
\text { Disagree }\end{array}$ & Mean & Rank \\
\hline $\begin{array}{l}\text { Domesticated grasscutter is not as nutritious as } \\
\text { compared to the one in the wild. }\end{array}$ & $8(5)$ & $68(42.8)$ & $78(49.1)$ & $5(3.1)$ & 2.50 & $2^{\mathrm{ND}}$ \\
$\begin{array}{l}\text { Domesticated grasscutter has lower nutritional } \\
\text { benefits compared to the one in the wild. }\end{array}$ & $6(3.8)$ & $35(21.9)$ & $\begin{array}{l}110 \\
(68.8)\end{array}$ & $9(5.6)$ & 2.76 & $1^{\mathrm{ST}}$ \\
$\begin{array}{l}\text { Grasscutter is not nutritious } \\
\begin{array}{l}\text { Grasscutter has higher protein content compared } \\
\text { to other animals. }\end{array}\end{array}$ & $21(13.3)$ & $81(51.3)$ & $52(32.9)$ & $4(2.5)$ & 2.25 & $4^{\mathrm{TH}}$ \\
$\begin{array}{l}\text { Grasscutter meat does not have any medicinal } \\
\text { value. }\end{array}$ & $22(13.8)$ & $83(51.9)$ & $40(25)$ & $15(9.4)$ & 2.30 & $3^{\mathrm{RD}}$ \\
\end{tabular}

Source: Field survey (2020).

Table 4: Participants' perception about the effect of grasscutter technology on their health situation

\begin{tabular}{|c|c|c|c|c|c|c|}
\hline Health Value & $\begin{array}{l}\text { Strongly } \\
\text { Agree }\end{array}$ & Agree & Disagree & $\begin{array}{l}\text { Strongly } \\
\text { Disagree }\end{array}$ & Mean & Rank \\
\hline $\begin{array}{l}\text { The odour emanating from the grass cutters' } \\
\text { habitat gives me allergy. }\end{array}$ & $9(5.6)$ & $88(55)$ & $38(23.8)$ & $25(15.60$ & 2.49 & $4^{\mathrm{TH}}$ \\
\hline $\begin{array}{l}\text { There is a high risk of grasscutter spreading } \\
\text { contagious diseases to humans. }\end{array}$ & $13(8.1)$ & $83(51.9)$ & $44(27.5)$ & $20(12.5)$ & 2.44 & $6^{\mathrm{TH}}$ \\
\hline Grasscutter meat is bad for diabetic patients. & $46(28.8)$ & $70(43.8)$ & $21(13.1)$ & $23(14.4)$ & 2.13 & $7^{\mathrm{TH}}$ \\
\hline Grasscutter meat is bad for hypertensive patients. & $20(12.5)$ & $69(43.1)$ & $46(28.8)$ & $25(15.6)$ & 2.47 & $5^{\mathrm{TH}}$ \\
\hline $\begin{array}{l}\text { There is risk of attack from domesticated } \\
\text { grasscutters on humans. }\end{array}$ & $14(8.8)$ & $72(45)$ & $53(33.1)$ & $21(13.1)$ & 2.51 & $3^{\mathrm{RD}}$ \\
\hline $\begin{array}{l}\text { The odour emanating from grasscutter habitat is } \\
\text { quite offensive. }\end{array}$ & $7(4.4)$ & $79(49.4)$ & $52(32.5)$ & $22(13.8)$ & 2.56 & $2^{\mathrm{ND}}$ \\
\hline $\begin{array}{l}\text { Humans consuming grasscutter meat are liable to } \\
\text { catching various diseases. }\end{array}$ & $11(6.9)$ & $48(30.2)$ & $91(57.2)$ & $9(5.7)$ & 2.62 & $1^{\mathrm{ST}}$ \\
\hline
\end{tabular}

Source: Extracted from field survey (2020).

Table 5: Frequency of respondents in ease of practice of grasscutter technology

\begin{tabular}{lllllll}
\hline Ease of Practice & $\begin{array}{l}\text { Strongly } \\
\text { Agree }\end{array}$ & Agree & Disagree & $\begin{array}{l}\text { Strongly } \\
\text { Disagree }\end{array}$ & Mean & Rank \\
\hline $\begin{array}{l}\text { It is not so convenient to rear grasscutter. } \\
\text { Grasscutter cannot be reared with other }\end{array}$ & $2(1.2)$ & $6(3.8)$ & $107(66.9)$ & $45(28.1)$ & 3.23 & $1^{\mathrm{ST}}$ \\
$\begin{array}{l}\text { animals } \\
\begin{array}{l}\text { Grasscutter farming is not easy to } \\
\text { practice. }\end{array}\end{array}$ & $73(45.6)$ & $51(31.9)$ & $102(63.8)$ & $48(30)$ & 3.22 & $2^{\mathrm{ND}}$ \\
\hline
\end{tabular}

Source: Extracted from field survey (2020). 
Table 5 revealed the response of respondents to 3 perception statements that bother on the ease of practice of grasscutter technology. Statement 1 'It is not so convenient to rear grasscutter' 2 'Grasscutter cannot be reared with other animals' and 3 'Grasscutter farming is not easy to practice' ranked $1^{\text {st }}$, $2^{\text {nd }}, 3^{\text {rd }}$ respectively with mean scores of $3.23,3.22$ and 1.84 respectively. According to this result, the following perception statements, 'the grasscutter is not convenient to rear' $(\mathrm{x}=2.62)$ and 'the grasscutter cannot be reared with the other animals $(x=2.62)$ had mean value above 2.76 , the grand mean value. The result implies that statements 1 and 2 are statements perceived by respondents as the main deterrents to willingness to practice. Table 6 presented the results of the response to the variables related with the willingness to adopt the grasscutter technology. The response revealed that the willingness to adopt is high with the highest as $93.1 \%$ to statement 4 'Assuming you have enough plot of land, will you be willing to rear grasscutter' and the lowest $79.4 \%$ to statement 8 'If you were given a breeding stock of grasscutter, will you be willing to rear them'. This implies that majority of the respondents are willing to rear grasscutter if variables like space, fund, availability of ready-made buyer and breeding stock and grasscutter feed, training are put into place. This result of this finding is in tandem with the study of Pantanali (1987) and Annor and Kushi (2008) that reported that fund and availability of a ready-made buyer were found to influence adoption.

Hypotheses Testing: 1. There is no significant relationship between personal characteristics of respondents and willingness to adopt

Table 7 presented the result of the correlation between the personal features of the respondents and their willingness to adopt the grasscutter technology. The result revealed that educational status $(\mathrm{r}=-0.221$; $\mathrm{p}=0.005)$, religion $(\mathrm{r}=0.244 ; \mathrm{p}=0.002)$, household size $(\mathrm{r}=0.343 ; \mathrm{p}=0.000)$ and both primary $(\mathrm{r}=0.270$; $\mathrm{p}=0.001)$ and secondary $(\mathrm{r}=-0.302 ; \mathrm{p}=0.000)$ occupation were significant at 0.05 level of significance. However, household and secondary occupations were the most significant. This result is against the findings of Okanlawon, Adeleke and Eniola, 2019 in which age was found to be significant in the adoption of the technology of grasscutter domestication. It also negates the findings of Ijeomah et al., (2016) in which educational status, household size and farming technology were found to be not significant on the willingness to adopt the grasscutter technology. However, Ijeomah, et al. (2016) supports the findings of this study in which age was found to be non-significant. The finding supported the result of Annor and Kushi (2008) which revealed that education influences adoption of grasscutter technology.

2. There is no significant relationship between perceived nutrition value and willingness to adopt

Table 6: Response of the participants on the variables related with grasscutter technology, a cross-sectional study on assessment of willingness to adopt grasscutter domestication technology

\begin{tabular}{lll}
\hline Indicators of Willingness to Adopt Grasscutter Domestication Technology & Yes N (\%) & No N (\%) \\
\hline Do you have a space in your house to domesticate grasscutter & $134(83.8)$ & $26(16.3)$ \\
Are you willing to rear grasscutter & $83(51.9)$ & $77(48.1)$ \\
Assuming you have access to fund, will you be willing to rear grasscutter & $147(91.9)$ & $13(8.1)$ \\
Assuming you have enough plot of land, will you be willing to rear grasscutter & $149(93.1)$ & $11(6.9)$ \\
If you have a ready-made buyer, will you be willing to rear grasscutter & $147(91.9)$ & $13(8.1)$ \\
If you have a ready-made supplier of grasscutter feed, will you be willing to rear them & $147(91.9)$ & $13(8.1)$ \\
If you were given training on grasscutter rearing, will you be willing to rear grasscutter & $147(91.9)$ & $13(8.1)$ \\
If you were given a breeding stock of grasscutter, will you be willing to rear them & $127(79.4)$ & $33(20.6)$ \\
If you were living in your own personal house, will you be willing to rear grasscutter & $135(84.4)$ & $25(15.6)$ \\
\hline
\end{tabular}
Source: Extracted from field survey (2020).

Table 7: Correlations between the Willingness to Adopt Grasscutter Technology and Selected Personal Characteristics

\begin{tabular}{lllll}
\hline Demographic Variables & Spearman's r & p- value & Decision & N \\
Age & -0.017 & 0.834 & Not Significant & 159 \\
\hline Sex & 0.152 & 0.057 & Not Significant & 159 \\
Educational Status & $-0.221^{* *}$ & 0.005 & Significant & 159 \\
Marital Status & 0.042 & 0.603 & Not Significant & 159 \\
Religion & $0.244^{* *}$ & 0.002 & Significant & 159 \\
Household size & $0.343^{* *}$ & 0.000 & Significant & 159 \\
Primary Occupation & $0.270^{* *}$ & 0.001 & Significant & 157 \\
Secondary Occupation & $-0.302^{* *}$ & 0.000 & Significant & 159 \\
\hline
\end{tabular}

Source: Computations from field survey (2020).

* Correlation is significant at the 0.05 level ** Correlation is significant at the 0.01 level.

Table 8: Correlation analysis showing relationship between Perceived nutrition value and willingness to adopt

\begin{tabular}{lllll}
\hline Variables Description & $\mathrm{r}-$ value & $\mathrm{p}$ - value & Remark & Decision \\
\hline Perceived Nutrition Value and Willingness to adopt & 0.223 & $0.005^{* *}$ & $\mathrm{H}_{0}$ Rejected & Significant
\end{tabular}

Source: Computations from field survey (2020). ${ }^{* *}$ Correlation is significant at the 0.01 level. 
The result of the finding on table 8 revealed the correlation between the perceived nutrition value of respondents and their willingness to adopt the grasscutter technology. The result revealed that the relationship was significant which means that the perceived nutrition value of grasscutter by respondents will influence their willingness to adopt the technology. The coefficient of correlation (R) is 0.223 and the significance value is $0.005(\mathrm{p}>0.01)$. This is in line with the result of the study of Teye and Odoi, 2020 which proved that consumers have greater preference for grasscutters in the wild because their perception of its higher nutritional benefits. Their preference had influence on their willingness to adopt the technology. 3. There is no significant relationship between perceived health issue and willingness to adopt

The result in table 9 revealed the correlation between the perceived health issue of respondents and their willingness to adopt the grasscutter technology. The result revealed that the relationship was significant, which implies that the perceived health issue of grasscutter by respondents will influence their willingness to adopt the technology. The coefficient of correlation $(\mathrm{R})$ is 0.233 and the significance value is $0.003(\mathrm{p}>0.05)$.

4. There is no relationship between perceived economic value of grasscutter and willingness to adopt

The correlation between the perceived economic value of respondents and their willingness to adopt the grasscutter technology was tested on table 10 . The result revealed that the relationship was significant; the implication is that the perceived economic value of grasscutter by respondents will influence their willingness to adopt the technology. The coefficient of correlation (R) is 0.244 and the significance value is $0.002(\mathrm{p}>0.05)$. The result from this study supported the study of Okanlawon Adeleke and Eniola, 2019 which states that improved economic value influences the willingness to adopt grasscutter rearing technology.

5. There is no significant difference between the perceived ease of practice and willingness to adopt

Table 9: Correlation analysis showing significant between perceived health issue and willingness to adopt

\begin{tabular}{lllll}
\hline Variables Description & r- value & $p$ - value & Remark & Decision \\
Perceived Health Issue and Willingness to adopt & 0.233 & $0.003^{* *}$ & $\mathrm{H}_{0}$ Rejected & Significant \\
\hline \multicolumn{4}{c}{ Source: Computations from field survey (2020): ** Correlation is significant at the 0.01 level. }
\end{tabular}

Table 10: Correlation analysis showing relationship between perceived economic value of grass cutter and willingness to adopt

\begin{tabular}{lllll}
\hline Variables Description & $\mathrm{r}$ - value & $\mathrm{p}$ - value & Remark & Decision \\
\hline $\begin{array}{l}\text { Perceived economic value of grass cutter and } \\
\text { Willingness to adopt }\end{array}$ & 0.244 & $0.002^{* *}$ & $\mathrm{H}_{0}$ Rejected & Significant \\
\hline
\end{tabular}

Source: Extracted from field study (2020).** Correlation is significant at the 0.01 level.

Table 11: T-test analysis showing significant difference between the perceived ease of rearing and willingness to adopt

\begin{tabular}{llllll}
\hline Variables Description & $\mathrm{M}$ & $\mathrm{SD}$ & $\mathrm{T}$ & $\mathrm{Df}$ & $\mathrm{P}$ \\
\hline Perceived ease of rearing & -1.703 & .786 & -27.2 & 157 & .000 \\
Willingness to adopt & -.302 & 1.272 & -2.9 & 158 & .003 \\
\hline \multicolumn{5}{c}{ Source: Computations from field survey (2020). }
\end{tabular}

Table 12: Correlation between residential apartment and willingness to adopt

\begin{tabular}{lllll}
\hline Variables Description & Pearson's $\mathrm{r}$ & $\mathrm{p}$ - value & Remark & Decision \\
\hline $\begin{array}{l}\text { Residential Apartment and Willingness } \\
\text { to Adopt }\end{array}$ & -0.030 & 0.710 & $\mathrm{H}_{0}$ Accepted & Not Significant \\
\hline
\end{tabular}

Source: Retrieved from field work (2020).

The result presented on table 11 revealed the relationship between respondents' perceived ease of practice and their willingness to adopt the grasscutter technology. The result revealed that the relationship was significant i.e. the perceived ease of rearing of grasscutter by respondents would influence their willingness to adopt the technology. The dependent variable in the hypothesis i.e. perceived ease of rearing was tested against willingness to adopt using T-test. Result shown in Table 11.0 showed that perceived ease of rearing was significantly related to willingness to adopt $(\mathrm{t}=-1.703 ; \mathrm{p}=0.000 ; \mathrm{t}=-2.9 ; \mathrm{p}=0.003)$. This is in agreement with the findings of Yeboah 2009 which stated that the waning support could be attributed mainly to challenges of appropriate housing and feeding for the domestic grasscutter production, relatively large initial capital investment required, the lack of readily available breeding stock, and problems of feed during the dry season and the many unresolved and poorly understood issues associated with diseases in captive grasscutters, making it difficult to domesticate.

6. There is no significant relationship between residential apartment and willingness to adopt

Table 12 revealed the correlation between the residential area of respondents and their willingness to adopt the grasscutter technology. The result revealed 
that the relationship is not significant i.e. the residential area of respondents will not influence their willingness to adopt the technology. The coefficient of correlation $(\mathrm{R})$ is -0.030 and the significance value is $0.710(\mathrm{p}>0.05)$. This result is contrary to the findings of Anang, Awuni and Mustapha (2011) in which 80\% of adopters were staying in their personal residents and $92 \%$ of non-adopters were staying in rented apartments. The correlation of house ownership and adoption in Anang, Awuni and Mustapha (2011) was positive and statistically significant.

Conclusion: The majority of the respondents show willingness to practice grasscutter rearing technology. This is a reality, if variables like space, adequate funding and availability of ready-made buyer, breeding stock and grasscutter feed, training of respondents are put into place. However, it is important to know that availability of plots of land to rear, fund and availability of a ready-made buyer and food for grasscutter, breeding stock and training of personnel were found to influence the willingness to adopt the technology most perceived health status, nutritional and economic value, ease of practice and some personal characteristics of the respondents were also found to be significant on the respondents' willingness to practice the grasscutter domestication technology in the Southwest, Nigeria. It is therefore recommended that extension agents and other stakeholders should intensify effort to give adequate training on the grasscutter domestication technology to urbanites, which will invariably shape their perceptions in every ramification to improve their rate of adoption. Moreover, the government should make funding, grasscutter pens, grasscutter feeds and readymade buyers available to encourage individuals willing to adopt the grasscutter domestication technology.

\section{REFERENCES}

Adedapo A. A. and Adekunle A. O. 2014 Economic aspects of grasscutter farming in southwest Nigeria: Implications for sustainable adoption and conservation. Inter. J. Sci. Engineer. Res. 4(10):17-23

Akinola, L. A. F., Etela, I. and Emiero, S. R. 2015 Grasscutter (Thryonomys swinderianus) Production in West Africa: Prospects, Challenges and role in disease transmission. American Journal of Experimental Agriculture; 6(4):196207

Anang, B. T., Awuni, J and Mustapha, A. (2011). Factors Affecting the Adoption of Grasscutter
(Thyronomys swinderianus) Farming in Sunyani Municipality, Brong Ahafo Region of Ghana

Annor, S. V. and Kushi, C. 2008. Factors Influencing the Adoption of Grasscutter Production in the Brong Ahafo Region of Ghana. Livestock Research for Rural Development (20)9

Cotten, S.R., Yost, E. A., Berkowsky, R. W., Winstead, V. and Anderson, W. A. 2016. Designing Technology Training for Older Adults in Continuining Care Retirement Communities, Boca Raton, FL: CRC. Press. doi:10.1201/9781315382463

Czaja, S.J. and Sharit, J. 2013.Designing Training and Instructional Programmes for older adults. Boca Raton, FL: CRC Press

Czaja, S. J, Charness, N., Fisk, A. D., Hertzog, C, Nair, S. N., Rogers, W. A. and Sharit, J. 2006. Factors predicting the use of technology: Findings from the centre for researcher and education on aging and technology enhancement (create). Psychology and Aging, 21, 333-352.

Hargittai, E. 2002. Second-level digital divide: Differences in People's Online Skills. First Monday, 7 retrieved from http://firstmonday.org/issues/issue7 4/hargittai/i ndex.html. \{Google Scholar\}

Ijeomah, H.M., Ofodile, E. A. U., Okereku, V. 2016. Challenges and Prospect of Grasscutter Farming in Selected Areas of Rivers State. Inter. J. Agric. 19 (1) $2600-2610$.

Okanlawon, O.M., Adeleke, O.A. and Eniola, P.O. 2019. Factors Influencing Grasscutter (Thyronomys swinderianus) Domestication in Rural Communities of Oyo State, Nigeria. $J$. Extent. 23(1), 24-36

Olatidoye, M., Alimi, T; Akinola, A. A. 2018. Determinants of technical efficiency in cotton production in the southern cotton growing zone of Nigeria: A stochastic production frontier approach. Asian J. Agric. 2(2):58-64

Olukole, S. G., Oyeyemi, M. O. and Oke, B. O. 2010. Gross anatomy of male reproductive organs of the domesticated grasscutter Thryonomys swinderianus Temmink). Proceedings of 25th Annual Conference of Nigerian Society for Animal Production. University of Ibadan, Nigeria; 268-271. 
Owen, O. J. and Amakiri, A. O. 2009. Rabbitary in Nigeria: The Potentialities, Opportunities and challenges: A Review. Proc. International Conf. on Global Food Crisis, Federal University of Technology, Owerri. April 19- 24th.Pp. 79 - 82.

Teye, M. and Odoi, F. N. A. 2020. Consumer Acceptance Carcass and Sensory Characteristics of Meats of Farms and Wild cane rats (Thyronomys swinderianus). Scientific African Volume 8. https://doi.org/10.1016/j.social.2020.e00461.

UNICEF Strategy for Improved Nutrition of Children and Women in Developing Countries. New York: UNICEF; 1990.

West Africa trends 2014. Bushmeat and the Future of Protein in West Africa. West Africa Trends Newsletter, Issue 9, 2014
Maduforo, A.N. 2010. Superstitions and Nutrition among Pregnant Women in Nwangele Local Government Area of Imo State, Nigeria. J. Res. Nutritional Develop: 8(2): 1-15

Pantanali, R. 1987. Factors Affecting Farmers Adoption Rates in a Subsistence Economy, in: The Design of Agricultural Investment ProjectsLessons from experience. FAO Technical Paper 6, Rome, 1989, Annex. 3,pp 2-5

Yeboah, C. A. 2009. Features and Profitability of Domestic Grasscutter Production in the Brong Ahafo Region A Thesis Submitted to The School of Graduate Studies, Kwame Nkrumah University of Science and Technology, Kumasi-Ghana 